\title{
The Corruption-Terrorism Nexus: A Panel Data Approach
}

\author{
Nahil Boussiga ${ }^{1} \&$ Malek Ghdamsi ${ }^{2}$ \\ ${ }^{1}$ Faculty of Economics and Management of Tunis, University of Tunis El Manar, Tunis, Tunisia \\ ${ }^{2}$ Faculty of Social Sciences, Laval University, Quebec, Canada \\ Correspondence: Nahil Boussiga, Faculty of Economics and Management of Tunis, University of Tunis El Manar, \\ Tunis, Tunisia. Tel: 216-29-358-989. E-mail: nahilboussiga@yahoo.fr
}

Received: July 27, 2016

Accepted: October 3, 2016

Online Published: October 25, 2016

doi:10.5539/ijef.v8n11p111

URL: http://dx.doi.org/10.5539/ijef.v8n11p111

\begin{abstract}
Corruption has been increasingly recognized as the major threat to economic development, political stability and peace. It is also acknowledged by the international community as the breeding ground for terrorism. This paper studies the relationship between corruption and terrorism in the long run. Previous studies examining the link between these two phenomena used only time series cointegration tests. In this paper, we consider a dataset for a panel of 123 developed and developing countries over the period 2003-2014. We use Pedroni's residual-based panel cointegration test and the error correction model-based panel cointegration test developed by Westerlund. In order to obtain more robust results, two different measures of corruption are utilized which are Corruption Perceptions Index (CPI) and Worldwide Control of Corruption Indicator (CC). The results of both tests reject the null hypothesis of no cointegration. we conclude that corruption and terrorism converge. Our findings corroborate results of previous studies.
\end{abstract}

Keywords: corruption, terrorism, organized crime, panel data, cointegration

\section{Introduction}

Corruption and terrorism constitute threats to international security. In fact, these phenomena have been the subject of many studies because of their alarming increase over the last two decades. According to Shelley (2014), terrorism is a result of ethnic and sectarian tensions as well as economic and demographic inequalities. Actually, this phenomenon is more widespread in developing economies. Indeed, these countries, due to the spread of corruption and misallocation of resources, export terror all over the world.

Moreover, several studies have examined the determinants of terrorism and concluded that this phenomenon depends strongly on political oppression, the weakness of public institutions, ineffective public governance and ethnic conflict (Krueger \& Maleckova, 2003; Abadie, 2006; Basuchoudhary \& Shughart, 2010). Freytag, Krüger, Meierrieks, and Schneider (2011) show that the deplorable socio-economic conditions have a considerable effect on terrorism. This situation is specific to developing countries. In fact, unemployed and marginalized young people are disillusioned by the unexplained wealth of corrupt decision-makers. Consequently, they are willing to risk their lives in search of a better future. In fact, bribery and money extortion are rife within public institutions making corruption a breeding ground for terrorism. These young people become easy prey for terrorist organizations who are following the methods of organized crime to finance their operations. Indeed, the main terrorist financing sources come from theft, kidnapping, drug trafficking, gunrunning and illegal immigrants.

During the last decade, the international political community calls for anti-corruption action. In 2005, the United Nations, recognizing the danger of transnational terrorism, signed the anti-corruption convention. This initiative followed the strategy of the World Bank for the promotion of good governance and the fight against corruption (GAC) adopted in 2007.

Previous studies on the relationship between corruption and terrorism used correlation coefficients and time series cointegration tests. In this paper, we examine the link between these two variables using panel cointegration tests. We will first conduct an overview of the theoretical discourse on corruption and terrorism. Then, we will examine the existence and nature of the Corruption-Terrorism Nexus in 123 countries over the period 2003-2014. Finally, we will proceed with detailed discussion of our most relevant empirical results. 


\section{Literature Review}

The last three decades have seen a worrisome increase in Islamic fundamentalism which is affecting not only the Middle Eastern and North African countries but also the Occident. By blaming the Western World for their political and social problems, Islamic extremist groups attract disfavored Muslims from Asia, Sub-Saharan Africa and the Middle East and North Africa (MENA). These organizations have declared a holy war (Jihad) on the Occident and all those who are in opposition to their views. The main objective of radical Islam groups is to establish Islamic States based on their own interpretations of the religious precepts of Islam (Sharia). The main reason for the spread of Islamic fundamentalism is the lack of democracy (De Poole-Robb \& Bailey, 2002). In addition, the majority of foreign fighters in Syria and Iraq come from the Organization of Islamic Corporation Member States (Global Terrorism Index Report, 2015).

Furthermore, KalbasiAnaraki (2012) argues that recent social upheavals in the Arab World result from economic problems and bad corruption scores. The author examines the long-run relationship between corruption and terrorism using data for 13 Arab countries. The results of Johansen Cointegration Tests show that corruption and the number of terrorist attacks are convergent over time in most countries. Moreover, KalbasiAnaraki (2012) tests for cointegration between economic freedom and casualties of terrorist activities. The results suggest that there is a long-run relationship between these two variables for most Arab countries.

In the same line of thought, Al-Badayneh (2009) studies the relationship between corruption and terrorism incidents in the Arab World over the period 1970-2007. The author finds out a significant negative correlation between corruption (Note 1) and terrorism (Note 2).

Moreover, according to the Report Peace and Corruption (2015) published by the Institute for Economics and Peace, corruption is highly correlated with peace indicators. In addition, The influence of peace on corruption is not statistically significant. It means that the relationship between the two variables has a one-way nature.

Corruption and terrorism both have profound consequences for developing economies. Several studies examined the effects of corruption, terrorism and organized crime on macroeconomic aggregates in developing countries.In fact, Shahrestani and Kalbasi Anaraki (2008) study the effects of terrorism on macroeconomic variables such as GDP growth and Foreign Direct Investments (FDI) using cross-sectional data for a sample of both developed and developing countries. They show that terrorism adversely affects FDI. Furthermore, Bandyopadhyay, Sandler and Younas et al. (2011) examine the impact of terrorism on FDI using a sample of 78 developing countries over the period 1984-2008. The authors assert that terrorism adversely and significantly affects FDI in developing countries. This negative effect has serious consequences on financial soundness. These developing economies, often weakened by high unemployment and low economic growth, are struggling to recover because of capital flight and declining attractiveness due to the lack of investor confidence. In most cases, these countries tend to borrow from international financial institutions to meet their public expenditure and reduce insolvency risk.

Moreover, Santana-Gallego, Rosselló-Nadal, and Fourie (2016) examine the effect of terrorism, crime and corruption on tourism for 171 countries between 1995 and 2013. Their results show that terrorism and crime have a negative effect on tourist arrivals especially those related to leisure activities. On the other side, corruption has no effect on leisure tourism but affects only business tourism.

Besides, Poole-Robb and Bailey (2002) argue that corrupt practices depend on how they are perceived. In fact, the definition of corrupt behavior generally depends on country's culture. Evidence from poor countries suggests that economic actors are more likely to get involved in corruption such as payoffs and bribery to escape tax illegally or maximize financial profits. Farah (2012) argues that Latin America governments are ineffective in fighting organized crime because of corruption and negligence. International community often puts blame on developing countries for corrupt, extortion and illicit financial activities around the World. However, the reality is quite different. In fact, Kaufmann (2004) suggests that firms from the Western World operating outside the Organization of Economic Development and Commerce (OECD) act differently than at national level. Actually, incentives for bribery abroad must be changed. The enforcement of the OECD Anti-Bribery Convention would henceforth become a necessity. Firms with corrupt activities abroad having recourse to Bank funding are already delisted by the World Bank. Kaufmann (2004) argues that crime can be overcome by focusing on domestic governance mechanisms and the quality of domestic institutions. However, terrorism needs a global challenge.

Much ink has been spilled trying to examine the Corruption-Organized crime-Terrorism Nexus called "Unholy Trinity". In fact, Shelley (2005) argues that organized crime, constituting the main source of funding for terrorist organizations, expands only in countries where corruption is widespread.

Figure 1 illustrates the links between corruption and terrorism. In order to transfer large amounts of money, 
criminals and terrorists become complicit with corrupt governments and their financial institutions (Tchachuk, 2005).

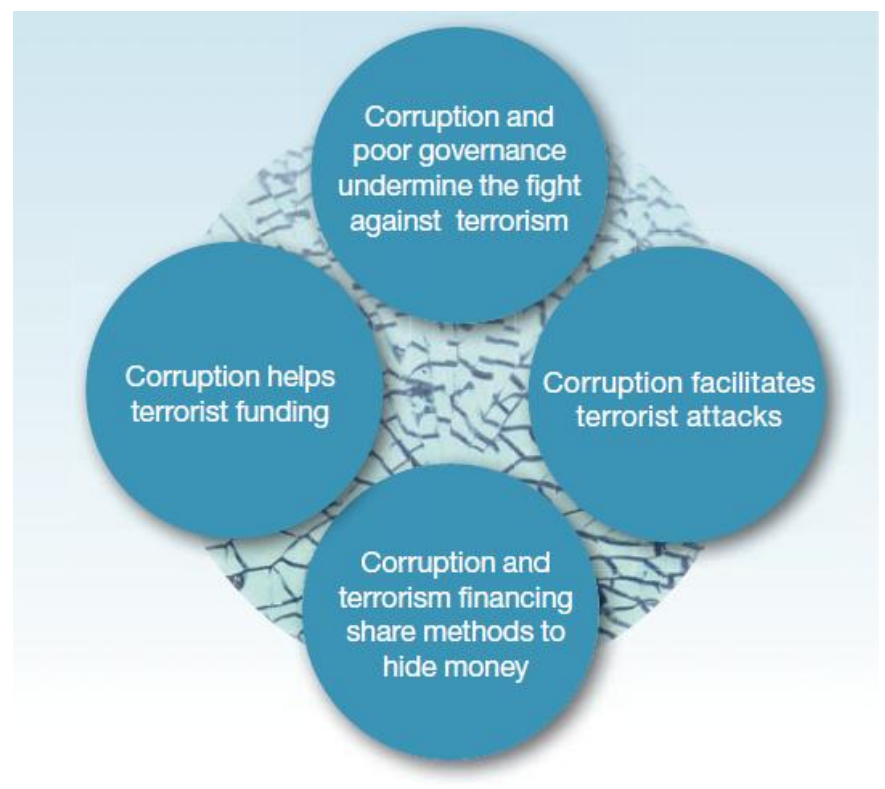

Figure 1. The connections between corruption and terrorism

Source: OECD (2016).

Thony (2005) affirms the soundness of strategies against money laundering. The author argues that objectives fixed by the international community in terms of fighting money laundering and terrorism financing are nevertheless far from being achieved because of insufficient supervision of illicit financial flows. Furthermore, Kaufman (2004) suggests that money laundering is linked to terrorism. On the other hand, the author denotes that money laundering is closely related to governance quality and therefore, being considered jointly to corruption as a determinant of the expansion of terrorism around the world.

It should be noted that organized crime comes in two types: traditional organized crime and transnational crime. These two types of criminal organizations do not have the same attitude towards terrorist organizations. Indeed, traditional criminal groups such as the Russian and Sicilian Mafia or the Chinese Triads are often nationalistic and do not seek to establish links with terrorist organizations. However, the new transnational crime whose main activities are drug trafficking and people smuggling are often anarchists and find their interest in alliance with terrorists, especially in the case of governments in transition or experiencing failure (Shelley, 2005). On the other hand, Hübschle (2011) points out that there is no significant empirical relationship between criminal and terrorist organizations in Southern Africa, especially in the post-transformation period.

This paper aims to complete literature by analyzing the link between corruption and terrorism employing a different method. In fact, panel cointegration tests are used in order to identify the existence and nature of this Nexus.

\section{Data and Methodology}

This paper examines the link between two global scourges: corruption and terrorism. We use panel cointegration tests in order to study the existence and nature of the relationship between these two variables. Tested hypotheses, data statistics and methodology are detailed below.

There is a variety of measures concerning corruption and terrorism. There are 3 different indexes of corruption which are Corruption Perceptions Index (CPI) (Note 3), Worldwide Control of Corruption Indicator (CC) (Note 4) and Freedom from Corruption Index (Note 5). In this study we opt for CPI and CC since Freedom from Corruption Index is derived from CPI.

Previous studies used number of terrorist attacks or number of casualties as measures of terrorism. In this paper, we use Global Terrorism Index which calculates a weighted sum of total number of incidents, total number of 
fatalities, total number of injuries and property damages measure. We estimate that GTI is the most comprehensive because it takes into account all terrorism indicators.

Figure 2 shows the global and by region CPI average scores for 2015. We notice that EU and Western Europe is the cleanest region. Inversely, Sub-Saharan Africa shows the highest corruption level.

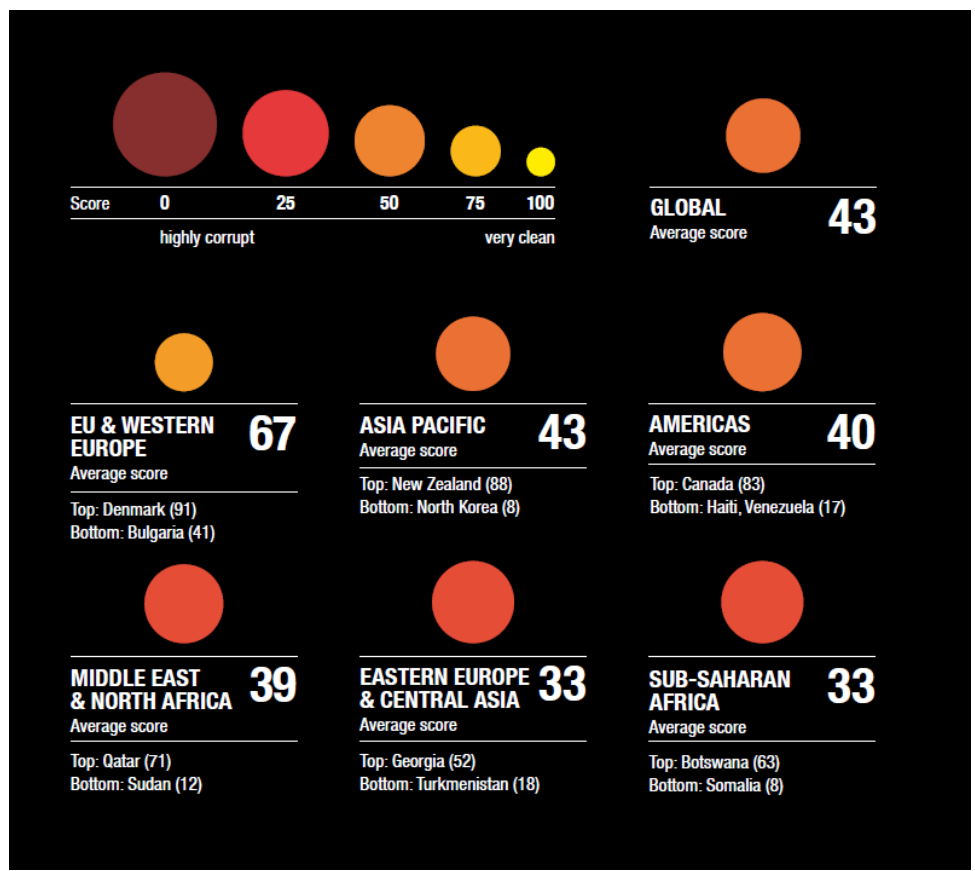

Figure 2. The global and by region CPI average scores for 2015

Source: Corruption Perceptions Index 2015.

Table 1 exhibits data descriptive statistics. In our sample, GTI scores vary from 0 to 10 . The highest GTI score corresponds to Iraq in 2014. In this study, It is more relevant to use panel cointegration tests than time series ones because of insufficient number of observations. In fact, our study period extends over no more than 12 years. We used panel data cointegration tests from Pedroni (2004) and Westerlund (2007).

Table 1. Data descriptive statistics

\begin{tabular}{lcccc}
\hline Variables & Mean & Standard Deviation & Minimum & Maximum \\
\hline GTI & 2.1276 & 2.3074 & 0 & 10 \\
CPI & 4.3526 & 2.3459 & 1.1 & 9.7 \\
CC & 0.0193 & 1.0442 & -1.8158 & 2.5526 \\
\hline
\end{tabular}

\section{Empirical Results}

First, we test for panel cointegration using the residual-based test of Pedroni (2004). Tables 2 and 3 exhibit Pedroni's cointegration test results of GTI and respectively CPI and CC. All test statistics are normalized to be distributed under $\mathrm{N}(0,1)$. Results show that all statistics except ADF (Note 6) value reject the null hypothesis of no cointegration.

The results of Westerlund's panel cointegration tests are depicted in Tables 4 to 7 . The main idea is to test for no cointegration by determining whether there exists error correction for individual panel members or for the panel as a whole. The Gt and Ga statistics test for the null hypothesis of no cointegration of at least one of the cross-sectional units. Pt and Pa statistics test for cointegration for the panel as a whole (Westerlund, 2007). Statistics reject the null hypothesis at a significance level of $1 \%$. The results suggest the existence of cointegration between corruption and terrorism.

In this study, the results of panel cointegration tests show that there is a long-run relationship between corruption 
and terrorism. Our findings corroborate previous studies examining the link between these two variables.

Table 2. Pedroni's panel cointegration tests between GTI and CPI

\begin{tabular}{lcc}
\hline Statistics & Panel & Group \\
\hline $\mathrm{v}$ & $4.519^{*}$ & - \\
$\mathrm{rho}$ & -1.517 & $2.519^{*}$ \\
$\mathrm{t}$ & $-3.66^{*}$ & $-2.86^{*}$ \\
$\mathrm{adf}$ & -1.103 & 0.233 \\
\hline
\end{tabular}

*Significant at lower than $10 \%$.

Table 3. Pedroni's panel cointegration tests between GTI and CC

\begin{tabular}{lcc}
\hline Statistics & Panel & Group \\
\hline $\mathrm{v}$ & $3.907 *$ & - \\
$\mathrm{rho}$ & -1.486 & $2.816^{*}$ \\
$\mathrm{t}$ & $-3.84^{*}$ & $-3.077 *$ \\
adf & -1.523 & -0.3287 \\
\hline
\end{tabular}

*Significant at lower than $10 \%$.

Table 4. Westerlund's panel cointegration tests between GTI and CPI (in levels)

\begin{tabular}{lcc}
\hline & & Lag $=0$ \\
\cline { 2 - 3 } Statistics & Value & P-value \\
\hline $\mathrm{Gt}$ & -1.919 & 0.000 \\
$\mathrm{Ga}$ & -7.191 & 0.000 \\
$\mathrm{Pt}$ & -11.894 & 0.000 \\
$\mathrm{~Pa}$ & -2.590 & 0.000 \\
\hline
\end{tabular}

Table 5. Westerlund's panel cointegration tests between GTI and CPI (lagged)

\begin{tabular}{lcc}
\hline & & Lag $=1$ \\
\cline { 2 - 3 } Statistics & Value & P-value \\
\hline $\mathrm{Gt}$ & -49.335 & 0.000 \\
$\mathrm{Ga}$ & $-1.1 \mathrm{e}+15$ & 0.000 \\
$\mathrm{Pt}$ & $-1.3 \mathrm{e}+10$ & 0.000 \\
$\mathrm{~Pa}$ & $-1.7 \mathrm{e}+15$ & 0.000 \\
\hline
\end{tabular}

Table 6. Westerlund's panel cointegration tests between GTI and CC (in levels)

\begin{tabular}{lcc}
\hline & & Lag $=0$ \\
\cline { 2 - 3 } Statistics & Value & P-value \\
\hline $\mathrm{Gt}$ & -1.757 & 0.000 \\
$\mathrm{Ga}$ & -2.757 & 0.995 \\
$\mathrm{Pt}$ & -9.374 & 0.001 \\
$\mathrm{~Pa}$ & -1.600 & 0.014 \\
\hline
\end{tabular}

Table 7. Westerlund's panel cointegration tests between GTI and CC (lagged)

\begin{tabular}{lcc}
\hline & & Lag $=1$ \\
\cline { 2 - 3 } Statistics & Value & P-value \\
\hline $\mathrm{Gt}$ & -50.262 & 0.000 \\
$\mathrm{Ga}$ & $-1.2 \mathrm{e}+15$ & 0.000 \\
$\mathrm{Pt}$ & $-9.8 \mathrm{e}+05$ & 0.000 \\
$\mathrm{~Pa}$ & $-5.6 \mathrm{e}+10$ & 0.000 \\
\hline
\end{tabular}




\section{Conclusions}

Previous studies on the relationship between corruption and terrorism used time series cointegtation tests and correlation coefficients. They have shown that these two phenomena converge over time. The main objective of this paper was to examine the Corruption-Terrorism Nexus using a data set for a panel of 123 countries over the period 2003-2014. In fact, GTI scores are available only from 2003. Panel data gave us a large number of observations. The results of panel cointegration tests developed by Pedroni (2004) and Westerlund (2007) confirm that there is a long-run relationship between these two phenomena. Our results corroborate existing literature. In our future research on corruption-terrorism relationship, we will take into account neighborhood effects by using spatial econometric methods.

International community calls for war against corruption and terrorism. Strategies against money laundering and terrorism financing are implemented as well. However, Western countries contribute in some way to corrupt practices in developing economies as OECD firms operating outside the organization are tempted by corruption (Kaufmann, 2004). On the other hand, most of governments in developing countries are constantly trying to hamper democratic processes helping corruption and terror flourish.

Unfortunately, globalization and technical progress make it more difficult for governments to supervise international money transfers. More efficient strategies are then required to face crime expansion.

Moreover, since the early 2000s, United States and Europe have been hit by terror attacks. We think that terrorism in Occident is not as serious as in developing countries in terms of number of casualties or attacks but it is considered more seriously by the international community. Given the increase of terrorist attacks, especially those committed by lone-wolf terrorists, the Western World face several challenges especially in terms of security, refugee policy, cooperation with Developing World and immigrant integration.

\section{References}

Abadie, A. (2004). Poverty, political freedom, and the roots of terrorism (No. w10859). National Bureau of Economic Research. http://dx.doi.org/10.3386/w10859

Al-Badayneh, M. D. (2009). Human Development, Peace, Corruption, and Terrorism in the Arab World. Paper presented at the 1st International Symposium on Terrorism and Transnational Crime, Antalya, Turkey. Retrieved from http://ikcrsjo.org/docs/Human_Development_Terrorism-1-2010.pdf

Bandyopadhyay, S., Sandler, T. M., \& Younas, J. (2011). Foreign direct investment, aid, and terrorism: an analysis of developing countries. Federal Reserve Bank of St. Louis Working Paper No 2011-004A. http://dx.doi.org/10.2139/ssrn.1745142

Basuchoudhary, A., \& Shughart, W. F. (2010). On ethnic conflict and the origins of transnational terrorism. Defence and Peace Economics, 21(1), 65-87. http://dx.doi.org/10.1080/10242690902868343

Farah, D. (2012). Transnational Organized Crime, Terrorism, and Criminalized States in Latin America: An Emerging Tier-One National Security Priority. Carlisle, PA: Strategic Studies Institute, U.S. Army War College. Retrieved from http://www.strategicstudiesinstitute.army.mil/pubs/display.cfm?pubID=1117

Freytag, A., Krüger, J. J., Meierrieks, D., \& Schneider, F. (2011). The origins of terrorism: Cross-country estimates of socio-economic determinants of terrorism. European Journal of Political Economy, 27, S5-S16. http://dx.doi.org/10.1016/j.ejpoleco.2011.06.009

Hübschle, A. (2011). From theory to practice: Exploring the organised crime-terror nexus in Sub-Saharan Africa. Perspectives on Terrorism, 5(3-4), 81-95.

Institute For Economics and Peace. (2015). Lowering corruption-A transformative factor for peace. Retrieved from http://economicsandpeace.org/wp-content/uploads/2015/06/Peace-and-Corruption.pdf

Kalbasi, A. N. (2012). Corruption and terrorism : Will they undermine the Arab Spring? 2012 Index of Economic Freedom.The Wall Street Journal and The Heritage Foundation, 57-68.

Kaufmann, D. (2004). Corruption, governance and security: Challenges for the rich countries and the world. http://dx.doi.org/10.2139/ssrn.605801

Krueger, A. B., \& Malečková, J. (2003). Education, poverty and terrorism: Is there a causal connection? The Journal of Economic Perspectives, 17(4), 119-144. http://dx.doi.org/10.1257/089533003772034925

Organisation for Economic Co-operation and Development (OECD). (2016). Terrorism, corruption and the criminal exploitation of natural resources. Retrieved from https://www.oecd.org/corruption/Terrorism-corruption-criminal-exploitation-natural-resources-2016.pdf 
Pedroni, P. (2004). Panel cointegration: Asymptotic and finite sample properties of pooled time series tests with an application to the PPP hypothesis. Econometric theory, 20(03), 597-625. http://dx.doi.org/10.1017/S0266466604203073

Poole-Robb, S., \& Bailey, A. (2002). RiskyBusiness: Corruption, fraud, terrorism and other threats to global business. London: Kogan Page.

Santana-Gallego, M., RossellÃ-Nadal, J., \& Fourie, J. (2016). The effects of terrorism, crime and corruption on tourism.ERSA Working Paper No. 595.

Shahrestani, H., \& Anaraki, N. K. (2008). ProtectivityVersus Productivity And Economic Growth: Empirical Evidence From Selected Countries. International Business \& Economics Research Journal (IBER), 7(10), 43-52.

Shelley, L. I. (2005). The Unholy Trinity: Transnational Crime, Corruption, and Terrorism. Brown Journal of World Affairs, 11(2), 101-111.

Shelley, L. I. (2014). Dirty entanglements: Corruption, crime, and terrorism. Cambridge University Press.

Thachuk, K. (2005). Corruption and international security. SAIS Review of International Affairs, 25(1), 143-152. http://dx.doi.org/10.1353/sais.2005.0020

Thony, J. F. (2002). Money laundering and terrorism financing: An overview. International Monetary Fund. Retrieved from https://www.imf.org/external/np/leg/sem/2002/cdmfl/eng/thony.pdf

Transparency International. (2015). Corruption Perceptions Index. Retrieved from http://www.transparency.org/cpi2015

Westerlund, J. (2007). Testing for error correction in panel data. Oxford Bulletin of Economics and Statistics, 69(6), 0305-9049. http://dx.doi.org/10.1111/j.1468-0084.2007.00477.x

\section{Notes}

Note 1. The author uses three different measures of corruption: Freedom from corruption, control of corruption and corruption perceptions index.

Note 2. Total number of terrorists' incidents and fatalities.

Note 3. Elaborated and published by Transparency International since 1995.

Note 4. One of the six Worldwide Governance Indicators, a research database initiated by Kaufmann and Kraay in 1999. See http://info.worldbank.org/governance/wgi/index.aspx\#home

Note 5. Derived from the CPI and part of the Economic Freedom Index. See http://www.heritage.org/index/freedom-from-corruption

Note 6. Augmented Dickey-Fuller which is a unit root test.

\section{Copyrights}

Copyright for this article is retained by the author(s), with first publication rights granted to the journal.

This is an open-access article distributed under the terms and conditions of the Creative Commons Attribution license (http://creativecommons.org/licenses/by/4.0/). 